\title{
Research council plan for Europe gets up steam
}

\section{Alison Abbott, Munich}

Europe needs an independent research council to support basic science - and the European Union (EU) should pay for it, a high-level group of experts has concluded.

The expert group, commissioned last year during the Danish presidency of the EU, has published an interim report outlining options for the creation of a continent-wide European Research Council (ERC).

The report will now form the basis of discussions with interested parties, including governments and scientists (see also page 451). The group's final report will be delivered to the Danish research councils in mid-November.

The debate about the ERC has been simmering for years. Almost everyone agrees that a transnational agency is needed to promote excellence in basic research in a continent where funding for science is fragmented along national lines. And most experts think

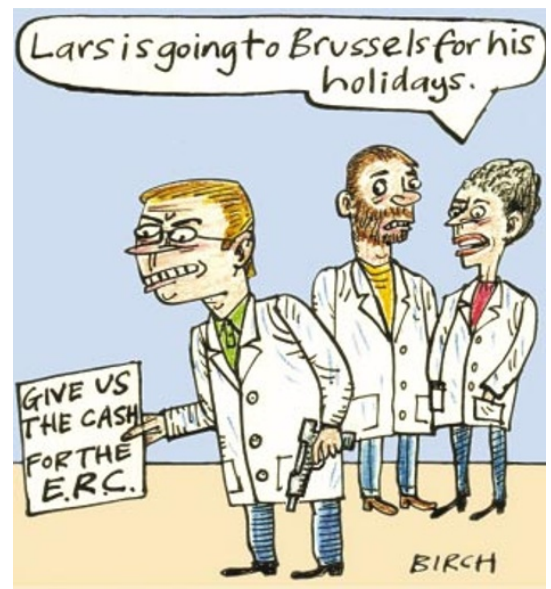

that the Framework programme, Europe's existing, heavily bureaucratized research scheme, is not up to the task, partly because of its emphasis on applied research.

But arguments over who should provide the funds have dominated discussions. Labouring the old linguists' joke that the first phrase to learn in a foreign language is "my friend will pay", some experts have argued that the EU should stump up the bulk of the cash, whereas others counter that member states should foot the bill, probably through their existing national agencies.

The expert group - chaired by Federico Mayor, a molecular biologist from the Autonomous University of Madrid and a former director general of the United Nations Educational, Scientific and Cultural Organization - falls squarely into the former camp. "We took as our starting point recent declarations made by EU heads of state that Europe cannot be competitive in the knowledge-based economy without a significant increase in research funding," says Mogens Flensted-Jensen, vice-chairman of the expert group and a representative of the Danish Research Councils. Flensted-Jensen also dismisses the idea that the ERC could be founded by adapting an existing organization, such as the Strasbourg-based European Science Foundation.

"If the ERC had to rely on making small improvements on the workings of current instruments like those of the European Science Foundation and the EU Framework programmes, and a bit of extra money from here and there, we are wasting our time," FlenstedJensen argues. "Our group was very clear on the point that the initiative needs new money."

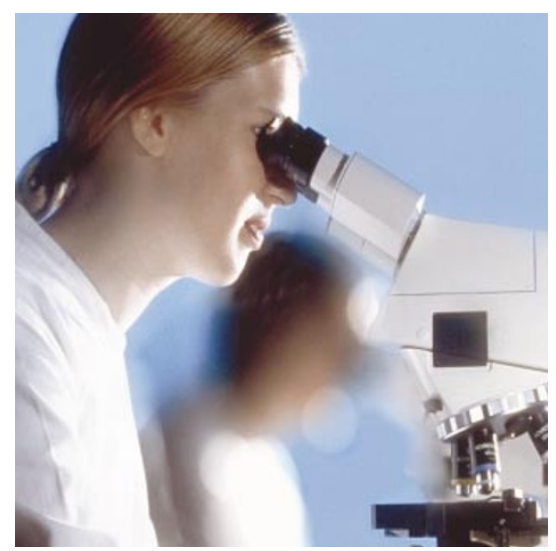

European research: who should pay?

The report recommends that a specific line should be created for the ERC in the EU's spending plans, which should be approved by the European Parliament. It suggests an annual budget of E2 billion (US $\$ 2.3$ billion).

The document also says that the ERC should be politically accountable to the European Parliament and its member states. Funding priorities and policies — such as mobility for researchers and access to large research facilities - should be agreed in an open manner with political bodies, it says. "But then the final distribution of grants should be decided on scientific quality without further political or geopolitical influence," says Flensted-Jensen.

European research commissioner Philippe Busquin says that the commission will set out its own report by the end of this year on how an ERC could be designed and funded.

\section{Wellcome to fund publication in open-access journals}

\section{Declan Butler, Paris}

One of the world's largest research charities, the UK-based Wellcome Trust, has lent its support to calls for 'open access' to the scientific literature.

A report to be released by Wellcome this week - An Economic Analysis of Scientific Research Publishing - says that the current system of thousands of subscription journals "does not operate in the interests of scientists and the public, but is instead dominated by a commercial market intent on improving its market position". In the report, the trust announces that it will allow scientists that it funds to use their grants to pay author charges required by open-access journals.

In a separate statement, the trust also pledged its support for online journals, such as those of the Public Library of Science
(PLoS), which will test alternatives to the 'reader pays' model of most research journals, which charge readers or libraries for subscriptions. Such open-access journals aim to transfer all publishing costs up front as a 'dissemination' fee paid by authors or their institutions, with papers then being made available free online.

"As a funder of research, we are committed to ensuring that the results of the science we fund are disseminated widely and are freely available to all," says Mark Walport, director of the Wellcome Trust. "Unfortunately, the distribution strategies currently used by publishers prevent this."

One of the obstacles to adoption of the alternative models may be scientists' reluctance or inability to pay dissemination fees - often around $\$ 1,500$ - when they can publish for free in subscription journals. By endorsing the use of its research grants to pay such fees, the trust is supporting the idea that publication costs should generally be included as part of overheads on research spending.

The US-based Howard Hughes Medical Institute has already agreed to provide its investigators with up to $\$ 3,000$ each in 2004 to cover open-access dissemination fees. In its report, Wellcome calls on other funding bodies to adopt similar policies. "The fundamental point is that as a research funder we have to question whether it is right that we, and others, are in the position of having to pay to read the results of the research that we fund," says Walport.

Next week's Nature will include a News Feature analysing business models for open-access publishing. 